\title{
Hubungan Pengetahuan dan Kepatuhan Diet dengan Kadar Gula Darah pada pasien Diabetes Melitus Di Poli Penyakit Dalam RSUD Idaman Banjarbaru Tahun 2018
}

Correlations of Knowledge and Compliance of Diet With Blood Sugar Levels of Patients With Diabetes Mellitus at Patients in Internal Medicine Polyclinic Idaman Banjabaru Hospital 2018

\author{
*Tri Ardianti K1, Zul Fina Fitri²
}

${ }^{1}$ STIKes Husada Borneo, Jl. A. Yani Km 30,5 No.4 Banjarbaru, Kalimantan Selatan 70712

${ }^{2}$ Alumni STIKES Husada Borneo, Jl. A. Yani Km 30,5 No.4 Banjarbaru, Kalimantan Selatan *korespondensi : mbakedworowati@gmail.com

\begin{abstract}
Diabetes mellitus is a chronic metabolic disorder due to the pancreas not producing enough insulin or the body cannot use insulin that is produced effectively. Indonesia has 10.3 million sufferers and standon $7^{\text {th }}$ position in the world after China, India, United States of America, Brazil, Russia, Mexico, on 2017 at the province of South Kalimantan's on $2^{\text {nd }}$ position that were 10.875, at Banjarbaru in 2017 is held on $2^{\text {nd }}$ ranked which had 2.968 cases, at Idaman Banjarbaru Hospital on the Internal Medicine Polyclinic there were 394 patients from January till April and estimated that will be 100 diabetes mellitus patients. This research is aimed to knowing the correlation of knowledge and compliance of diet with blood sugar levels of patients with diabetes mellitus at the Internal Medicine Polyclinic in Banjarbaru Hospital 2018. This type of research is a description of correlation research using cross sectional design. This research was carried out to 55 respondents. The results that tested using Chi-Square with a value of $\alpha=0.1$ proved to have no correlation of knowledge with blood sugar levels $(p=0.234)$ and proved to have a correlation of adherence to diet with blood sugar levels $(p=0.00)$. From this study it can be concluded that knowledge proved to have not correlation with blood sugar levels and dietary compliance was shown to have a correlation with blood sugar levels in diabetes mellitus patients at Internal Medicine Polyclinic Idaman Banjarbaru Hospital 2018.
\end{abstract}

Keywords : Knowledge, Compliance Diet, Blood Sugar Levels Diabetes Melitus.

\section{Pendahuluan}

Diabetes melitus (DM) merupakan penyakit gangguan metabolik menahun akibat pankreas tidak memproduksi cukup insulin atau Tubuh tidak dapat menggunakan insulin yang diproduksi secara efektif. Insulin adalah hormon yang mengatur keseimbangan kadar gula darah. Akibatnya terjadi peningkatan konsentrasi glukosa di dalam darah (1).

Berdasarkan International Diabetes Federation tahun 2017 tingkat prevalensi global penderita DM pada tahun 2015 sebesar $9,9 \%$ dari keseluruhan penduduk di dunia dan pada tahun 2017 menjadi 911 juta kasus. Indonesia menempati urutan ke 7 dengan penderita DM sejumlah 10,3 juta penderita setelah Cina, India, Amerika Serikat, Brazil, Rusia, Mexico (2). Menurut data Riset Kesehatan Dasar (Riskesdas) tahun 2013 menunjukkan bahwa terjadi peningkatan prevalensi pada penderita diabetes melitus di Indonesia yang diperoleh berdasarkan diagnosis dokter atau gejala yaitu $1,1 \%$ pada tahun 2007 menjadi 2,1\% pada tahun 2013 (3).

Berdasarkan Dinas Kesehatan Provinsi Kalimantan Selatan tahun 2017 DM menduduki peringkat ke-2 dan tercatat 10.875 penderita DM di wilayah Provinsi 
Kalimantan Selatan (4). Menurut data Dinas Kesehatan Banjarbaru tahun 2017 DM menduduki peringkat ke-2 dan tercatat ada 2.968 penderita DM di wilayah Banjarbaru(5). Data survei pendahuluan di Poli penyakit dalam RSUD Idaman Banjarbaru, pada pasien penderita DM dari bulan Januari - April sebanyak 394 dan setiap bulannya diperkirakan ada 100 pasien penderita DM (6).

Faktor yang mempengaruhi pengendalian kadar gula darah adalah dengan pengetahuan dan kepatuhan diet, apabila tidak dikendalikan dengan baik maka akan terjadi penurunan dan peningkatan kadar gula darah yang tidak terkendali. Pengetahuan merupakan faktor yang sangat penting dalam menentukan perilaku seseorang terhadap makanan sehingga dapat mengendalikan dan mengontrol kadar gula darah. Pengetahuan biasanya didahului dengan tahu, selanjutnya tindakan yang didasari oleh pengetahuan dan akan bersifat lebih baik dari pada tindakan yang tidak didasari oleh pengetahuan (7).

Kepatuhan diet merupakan salah satu faktor yang dapat mempengaruhi kadar gula darah. Pasien yang tidak patuh terhadap dietnya akan mempengaruhi gula darahnya menjadi kurang baik, bahkan tidak terkontrol, hal ini akan mengakibatkan komplikasi (8).

Penderita DM penting untuk mematuhi serangkaian pemeriksaan seperti pengontrolan gula darah. Bila pengontrolan gula darah pada penderita DM rendah maka dapat menyebabkan tidak terkontrolnya kadar gula darah yang akan menyebabkan komplikasi (9).

Berdasarkan permasalahan tersebut peneliti tertarik untuk mengetahui Hubungan Pengetahuan dan Kepatuhan Diet dengan Kadar Gula Darah pada Pasien DM di Poli Penyakit Dalam RSUD Idaman Banjarbaru 2018.

\section{Metode Penelitian}

Jenis penelitian ini adalah penelitian deskripsi korelasi menggunakan rancangan cross sectional.
Populasi pada penelitian ini adalah pasien diabetes melitus di Poli Penyakit Dalam RSUD Idaman Banjarbaru. Sampel pada penelitian ini didapatkan menggunakan teknik total sampling, sejumlah 55 responden.

Variabel bebas dalam penelitian ini adalah pengetahuan dan kepatuhan diet, sedangkan variabel terikatnya adalah kadar gula darah pada pasien DM.

Teknik pengumpulan data dilakukan dengan menggunakan kuesioner dengan wawancara dan juga dari data rekam medis. Teknik analisis data menggunakan uji chisquare dengan $\alpha=0,1$.

\section{Hasil Penelitian}

1. Analisa Univariat

Tabel 1 Faktor pencetus DM pada responden di Poli Penyakit Dalam RSUD Idaman Banjarbaru

\begin{tabular}{|c|c|c|}
\hline \multirow[t]{2}{*}{ Umur } & \multicolumn{2}{|c|}{$\begin{array}{c}\text { Jumlah } \\
\text { Responden }\end{array}$} \\
\hline & $\mathbf{N}$ & $\%$ \\
\hline $36-40$ tahun & 4 & 7,3 \\
\hline $41-46$ tahun & 13 & 23,6 \\
\hline $47-52$ tahun & 8 & 14,5 \\
\hline $53-58$ tahun & 24 & 43,6 \\
\hline $59-64$ tahun & 6 & 10,9 \\
\hline Jumlah & 55 & 100 \\
\hline \multicolumn{3}{|l|}{ Jenis Kelamin } \\
\hline Laki - laki & 23 & 41,8 \\
\hline Perempuan & 32 & 58,2 \\
\hline Jumlah & 55 & 100 \\
\hline \multicolumn{3}{|l|}{ Pendidikan Terakhir } \\
\hline SD & 13 & 23,6 \\
\hline SLTP & 2 & 3,6 \\
\hline SLTA & 18 & 32,7 \\
\hline Akademi/PT & 22 & 40 \\
\hline Jumlah & 55 & 100 \\
\hline \multicolumn{3}{|l|}{ Pekerjaan } \\
\hline Pensiun/Tidak bekerja & 8 & 14,5 \\
\hline PNS/TNI/POLRI & 9 & 16,4 \\
\hline Wiraswasta/Pedagang & 7 & 12,7 \\
\hline Ibu Rumah Tangga & 17 & 30,9 \\
\hline Buruh/ Tukang & 4 & 7,3 \\
\hline Lain - lain & 10 & 18,2 \\
\hline Jumlah & 55 & 100 \\
\hline \multicolumn{3}{|l|}{ Riwayat Keluarga DM } \\
\hline Ada & 30 & 54,5 \\
\hline Tidak Ada & 25 & 45,5 \\
\hline Jumlah & 55 & 100 \\
\hline
\end{tabular}




\begin{tabular}{lcc}
\hline 1 tahun & 9 & 16,4 \\
\hline 2 tahun & 11 & 20 \\
\hline 3 tahun & 9 & 16,4 \\
\hline 4 tahun & 7 & 12,7 \\
\hline 5 tahun & 6 & 10,9 \\
\hline 6 tahun & 6 & 10,9 \\
\hline 7 tahun & 7 & 12,7 \\
\hline Jumlah & 55 & 100 \\
\hline Dukungan Keluarga & & \\
Pada Pasien DM & & \\
\hline Ada & 49 & 89,1 \\
\hline Tidak Ada & 6 & 10,9 \\
\hline Jumlah & 55 & 100 \\
\hline Pengetahuan & & \\
\hline Kurang & 0 & 0 \\
\hline Cukup & 9 & 16,4 \\
\hline Baik & 46 & 83,6 \\
\hline Jumlah & 55 & 100 \\
\hline Kepatuhan Diet & & \\
\hline Selalu Mematuhi & 7 & 12,7 \\
\hline Sering Mematuhi & 18 & 32,7 \\
\hline Kadang Mematuhi & 30 & 54,5 \\
\hline Jarang Mematuhi & 0 & 0 \\
\hline Tidak Mematuhi & 0 & 0 \\
\hline Jumlah & 50 & 100 \\
\hline Kadar Gula Darah & & \\
\hline Tidak Terkontrol & 33 & 60 \\
\hline Terkontrol & 22 & 40 \\
\hline Jumlah & 50 & 100 \\
\hline & & \\
\hline
\end{tabular}

Berdasarkan tabel di atas diketahui bahwa sebagian besar responden di Poli Penyakit Dalam RSUD Idaman Banjarbaru berumur $53-58$ tahun yaitu 24 responden $(43,6 \%)$, sebagian besar berjenis kelamin perempuan yaitu 32 responden (58.2\%), berpendidikan terakhir Akademi/PT yaitu 22 responden (40\%). Kebanyakan responden sebagai seorang ibu rumah tangga yaitu 17 responden (30,9\%). Responden mempunyai riwayat keluarga menderita DM yaitu 30 responden $(54,5 \%)$

Responden sebagian besar menderita DM selama 2 tahun yaitu 11 responden (20\%). Responden kebanyakan mendapat dukungan dari keluarga atas pengobatan DM yaitu 49 responden $(89,1 \%)$. Responden memiliki tingkat pengetahuan yang baik yaitu 46 responden (83,6\%), responden hanya kadang saja mematuhi diet yaitu sebesar 30 responden (54,5\%) dan responden sebagian besar memiliki

kadar gula darah tidak terkontrol yaitu 33 responden (60\%).

A. Analisa Bivariat

1. Hubungan antara Pengetahuan dengan Kadar Gula Darah DM di Poli Penyakit Dalam RSUD Idaman Banjarbaru

Tabel 11 Hubungan antara Pengetahuan dengan Kadar Gula Darah DM Tipe 2 di Poli Penyakit Dalam RSUD Idaman Banjarbaru

\begin{tabular}{lccc}
\hline Pengetahuan & \multicolumn{2}{l}{ Kadar Gula darah } & Total \\
\cline { 2 - 3 } & $\begin{array}{l}\text { Tidak } \\
\text { Terkontrol }\end{array}$ & $\begin{array}{l}\text { Terkon } \\
\text { trol }\end{array}$ \\
& 7 & 2 & 9 \\
\hline Cukup & 26 & 20 & 46 \\
\hline Baik & 33 & 22 & 55 \\
\hline Jumlah & & & \\
\hline
\end{tabular}

Dari tabel diatas dari 46 responden yang berpengetahuan baik sebanyak 26 responden memiliki kadar gula darah tidak terkontrol sedangkan dari 9 responden berpengetahuan cukup sebanyak 7 responden memiliki kadar gula darah tidak terkontrol.

Berdasarkan hasil analisa uji statistik (Chi Square) $p$-value 0,23. Terlihat $p$-value $=0,23>\alpha(0,1)$. Maka Ho diterima, hasil dapat disimpulkan pengetahuan terbukti tidak memiliki hubungan dengan kadar gula darah pasien diabetes melitus di Poli Penyakit Dalam RSUD Idaman Banjarbaru.

2. Hubungan antara Kepatuhan Diet dengan Kadar Gula Darah Pasien DM di Poli Penyakit Dalam RSUD Idaman Banjarbaru

Tabel 12 Hubungan antara Kepatuhan Diet dengan Kadar Gula Darah Pasien Diabetes Melitus di Poli Penyakit Dalam RSUD Idaman Banjarbaru

Kepatuhan Diet Kadar Gula darah Total

\begin{tabular}{lccc}
\cline { 2 - 3 } & $\begin{array}{l}\text { Tidak } \\
\text { Terko } \\
\text { ntrol }\end{array}$ & $\begin{array}{l}\text { Terkontro } \\
\text { I }\end{array}$ & \\
\hline Selalu Mematuhi & 0 & 7 & 7 \\
\hline Sering Mematuhi & 4 & 14 & 18 \\
\hline Kadang Mematuhi & 29 & 1 & 30 \\
\hline Jumlah & 33 & 22 & 55 \\
\hline Sumber : Data Primer, 2018 & &
\end{tabular}


Dari tabel diatas dari 30 responden kadang mematuhi diet, sebanyak 29 responden yang memiliki kadar gula darah tidak terkontrol, sedangkan dari 18 responden sering mematuhi diet, sebanyak 14 responden yang memiliki kadar gula darah yang terkontrol.

Berdasarkan hasil analisa uji statistik (Chi Square) $\mathrm{p}$-value 0,00. Terlihat $\mathrm{p}$-value $=0,00<\alpha(0,1)$. Maka Ho ditolak, hasil dapat disimpulkan kepatuhan diet terbukti memiliki hubungan dengan kadar gula darah pasien diabetes melitus di Poli Penyakit Dalam RSUD Idaman Banjarbaru.

\section{Pembahasan}

A. Pembahasan Analisa Univariat

Sebagian besar responden di Poli Penyakit Dalam RSUD Idaman berusia 53 58 tahun yaitu sebanyak 24 responden $(43,6 \%)$. Usia sangat erat kaitannya dengan kenaikan kadar gula darah, semakin bertambah umur akan meningkat prevalensi DM dan gangguan glukosa akan semakin tinggi. Sehingga seseorang dengan DM hanya dapat mempertahankan kadar gula dalam darah agar tetap normal (11).

Responden sebagian besar berjenis kelamin perempuan yaitu sebanyak 32 responden (58,2\%). Menurut Damayanti (2010) kejadian DM pada perempuan lebih tinggi daripada laki-laki. Perempuan lebih berisiko terkena DM karena secara fisik perempuan memiliki peluang peningkatan indeks masa tubuh yang lebih besar. Siklus bulanan pasca-menopouse yang membuat distribusi lemak tubuh menjadi mudah terakumulasi akibat proses hormonal tersebut sehingga perempuan berisiko menderita DM .

Pendidikan responden sebagian besar Akademi/PT yaitu sebanyak 22 responden (40\%). Penderita yang berpendidikan tinggi akan memiliki pemahaman lebih baik mengenai penyakit diabetes dan efeknya terhadap kesehatan hidup. Orang dengan tingkat pendidikan tinggi biasanya akan memiliki banyak pengetahuan tentang kesehatan. Menurut penelitian Sutrisno (2011) mengungkapkan pendidikan merupakan faktor yang dapat mempengaruhi pengetahuan seseorang, semakin tinggi pendidikan seseorang, maka akan semakin mudah dalam menerima informasi Sebaliknya jika pendidikan rendah, maka akan menghambat perkembangan sikap seseorang terhadap penerimaan informasi (13).

Sebagian besar reponden bekerja sebagai ibu rumah tangga yaitu sebanyak 17 responden (30.9\%). Menurut penelitian Martalena dalam Anani dkk, (2012) jenis pekerjaan pasien DM mempengaruhi kebiasaan makan responden. Responden yang sebagian besar adalah ibu rumah tangga dan wiraswasta membuat jadwal makan tidak konsisten setiap hari, sehingga jadwal makan sangat beragam antara satu pasien DM dengan pasien DM lainnya. Berbeda jika bekerja di kantor atau mempunyai aktivitas pekerjaan yang dibatasi oleh waktu, sehingga kepatuhan terhadap jadwal makan dapat tergambarkan (14).

Responden sebagian besar mempunyai riwayat keluarga mendeita DM yaitu sebanyak 30 responden (54,5\%). Orang yang memiliki riwayat keluarga menderita DM lebih berisiko dari pada orang yang tidak memiliki riwayat keluarga menderita DM. Hal ini selaras dengan penelitian Wicaksano (2011) menunjukkan terjadinya DM tipe-2 akan meningkat dua sampai enam kali lipat jika orang tua atau saudara kandung mengalami penyakit ini (15).

Responden sebagian besar menderita DM selama 2 tahun yaitu sebanyak 11 responden (20\%). Menurut penelitian Setiyorini semakin lama seseorang menderita penyakit DM, pengetahuan semakin bertambah. Hal ini dikarenakan pasien akan berusaha mencari sumber informasi sebanyak-banyaknya untuk mencegah terjadinya komplikasi (16).

Sebagian besar responden mendapat dukungan Adanya dukungan dari keluarga atas pengobatan DM yaitu sebanyak 49 responden $(89,1 \%)$. Menurut Setiadi Dukungan keluarga dapat membantu penderita DM dalam melanjutkan hidup. Dengan adanya dukungan keluarga, 
penderita DM ini merasa dicintai, masih dibutuhkan oleh keluarga dan hidupnya masih berharga untuk orang lain termasuk untuk keluarganya (15). Sedangkan menurut Arsana menjelaskan dukungan dari keluarga dalam hal diet bermanfaat dalam mengkontrol jumlah makanan serta jam makan (17).

Responden memiliki tingkat pengetahuan yang baik yaitu sebanyak 46 responden (83,6\%). Dikarenakan pengetahuan responden yang baik dapat dipengaruhi karena kemajuan teknologi informasi. Pengetahuan yang dimiliki akan mempengaruhi perilaku penderita DM dalam melakukan penatalaksanaan, memilih atau memutuskan tindakan yang akan dilakukan dalam mempertahankan status kesehatannya, khususnya informasi tentang penatalaksanaan diabetes melitus yang terkait dengan pengaturan makan / diet (18).

Responden sebagian besar kadang mematuhi diet yaitu sebanyak 30 responden (54,5\%). Pasien DM di RSUD Idaman rata-rata kadang mematuhi diet yang dianjurkan, meskipun pernah mendapatkan konsultasi gizi terutama dalam hal mematuhi diet akan tetapi rendahnya perilaku membuat responden tidak konsisten dalam menjalankan diet yang dianjurkan.

Sebagian besar kadar gula responden tidak terkontrol yaitu sebanyak 33 responden (60\%). Hal ini disebabkan selain penyakit DM yang diderita adapun karena pola makan yang salah seperti makan tidak sesuai anjuran dalam bentuk jumlah, jenis dan jadwal sehingga apabila tidak mematuhi anjuran diet yang diberikan akan mempengaruhi kadar gula darahnya. Penderita DM pengaturan sistem kadar gulanya terganggu. Insulin tidak cukup untuk mengatasi dan akibatnya kadar gula di dalam darah bertambah tinggi. (19).

\section{B. Analisis Bivariat}

1. Hubungan antara Pengetahuan dengan Kadar Gula Darah Pasien Diabetes Melitus
Hasil penelitian berdasarkan pengetahuan dengan kadar gula darah dapat diketahui dari 46 responden yang berpengetahuan baik sebanyak 26 responden memiliki kadar gula darah tidak terkontrol sedangkan 9 responden berpengetahuan cukup sebanyak 7 responden memiliki kadar gula darah tidak terkontrol.

Hasil analisa uji statistik (Chi Square) $\mathrm{p}$-value 0,23 . Terlihat $\mathrm{p}$-value $=0,23>\alpha$ $(0,1)$. Maka Ho diterima, hasil dapat disimpulkan pengetahuan terbukti tidak ada hubungan dengan kadar gula darah pasien diabetes melitus di Poli Penyakit Dalam RSUD Idaman Banjarbaru. Menurut penelitian Manan S pengetahuan yang baik tidak menjamin tindakan pasien baik terhadap upaya pengendalian kadar gula darah. Karena tindakan berasal dari keinginan dan juga motivasi dari dirinya, sehingga kesadaran dan penerapan pasien terhadap perilaku hidup sehat masih kurang yang menimbulkan kurangnya terkendali kadar gula darah (20).

Selain itu, banyaknya penderita DM yang telah memiliki tingkat pengetahuan yang baik karena dipicu oleh beberapa faktor yang mempengaruhi pengetahuan itu sendiri, seperti usia yang matang dan latar belakang pendidikan yang tinggi sehingga meningkatkan kemampuan analisa responden terhadap pengetahuan tentang faktor risiko DM, serta faktor pengalaman penderita DM selama beberapa tahun dan telah melakukan beberapa upaya seperti pengendalian konsumsi gula.

2. Hubungan antara Kepatuhan Diet dengan Kadar Gula Darah Pasien Diabetes Melitus

Hasil penelitian kepatuhan diet dengan kadar gula darah sebagian besar kadang mematuhi diet yaitu sebanyak 30 responden, sebanyak 29 responden yang memiliki kadar gula darah tidak terkontrol, sedangkan 18 responden sering mematuhi diet, sebanyak 14 responden yang memiliki kadar gula darah yang terkontrol.

Hasil analisa uji statistik (Chi Square) $\mathrm{p}$-value 0,00 . Terlihat $\mathrm{p}$-value $=0,00<\alpha$ $(0,1)$. Maka Ho ditolak, hasil dapat 
disimpulkan kepatuhan diet terbukti memiliki hubungan dengan kadar gula darah pasien diabetes melitus di Poli Penyakit Dalam RSUD Idaman Banjarbaru.

Kepatuhan diet merupakan terapi diet yang terdapat dalam penatalaksanaan DM untuk pengendalian kadar gula darah. Dimana kepatuhan merupakan wujud tingkah laku pasien dalam mengontrol kadar gula darah. Kepatuhan diet didasarkan pada aspek $3 \mathrm{~J}$, yaitu patuh jadwal, jenis dan jumlah (10).

Pasien yang patuh akan mempunyai kadar gula darahnya yang terkontrol, dengan kadar gula darah yang terkontrol terus menerus akan dapat mencegah komplikasi akut dan mengurangi resiko komplikasi jangka panjang. Sebaliknya bagi pasien yang tidak patuh akan mempengaruhi kadar gula darahnya menjadi tidak terkontrol, hal ini akan mengakibatkan timbulnya komplikasi.

\section{Kesimpulan}

Berdasarkan hasil penelitian di Poli Penyakit dalam RSUD Idaman Banjabaru Tahun 2018 diperoleh kesimpulan sebagai berikut :

Kadar gula darah tidak terkontrol sebanyak 33 responden (60\%) dan kadar gula darah terkontrol sebanyak 22 responden (40\%). Pengetahuan responden dalam ketegori baik sebanyak 46 responden $(83,6 \%)$ dan pengetahuan responden dalam kategori cukup sebanyak 9 responden $(16,4 \%)$. Kepatuhan diet dalam kategori kadang mematuhi diet sebanyak 30 responden $(54,5 \%)$ dan kepatuhan diet dalam kategori selalu mematuhi diet sebanyak 7 responden (12,7\%).

Pengetahuan terbukti tidak memiliki hubungan dengan kadar gula darah pada pasien DM di RSUD Idaman Banjarbaru, pvalue $=0,23>\alpha(0,1)$. Kepatuhan diet terbukti memiliki hubungan dengan kadar gula darah pada pasien DM di RSUD Idaman Banjarbaru, $p$-value $=0,00<\alpha(0,1)$.

\section{Daftar Pustaka}

1. Departemen Kesehatan Republik Indonesia (Depkes RI). (Pedoman pengendalian diabetes melitus dan penyakit metabolik. Jakarta. 2008

2. International Diabetes Federation (IDF). Diabetes atlas 7th edition. Brussels: International Diabetes Federation.2017. Available from: http://www. diabetes atlas. org/. [Accessed 29 maret 2018].

3. Kementrian Kesehatan RI. Riset kesehatan dasar laporan nasional. Jakarta : Badan Penelitian \& Pengembangan kesehatan DepKes RI.2013. Available from: http://www.depkes.go.id/resources/dow nload/general/Hasil\%20Riskesdas\%2 02013.pdf. [Accessed 2 april 2018].

4. Dinas Kesehatan Provinsi Kalimantan Selatan. Data diabetes melitus tahun 2017. Banjarmasin.

5. Dinas Kesehatan Banjarbaru. Data diabetes melitus tahun 2017. Banjarbaru.

6. Rekam Medik Poli Penyaki Dalam. Data rekam medik pasien diabetes melitus. Banjarbaru : RSUD Idaman. 2018

7. Pujiastuti E. Hubungan pengetahuan dan motivasi dengan kepatuhan diet pada pasien diabetes melitus tipe 2 di poliklinik penyakit dalam RSUD DR.Soehadi Prijonegoro Sragen. Program Studi S1 Keperawatan STIKes Kusuma Husada Surakarta. Skripsi. 2016

8. Niven. Psikologi kesehatan: Pengantar Untuk Perawat dan Profesional. Jakarta : EGC. 2008

9. Lailatul L. Hubungan durasi penyakit dan kadar gula darah dengan keluhan subyektif penderita diabetes melitus. Jurnal Berkala Epidemiologi, 5 (2): 231239. 2017

10. Vinti D. Hubungan pengetahuan,sikap dan kepatuhan diet dengan kadar gula darah pada pasien diabetes melitus di poliklinik khusus penyakit dalam RSUP Dr.M.Djamil Padang Tahun 2015. Sumatra barat :Politeknik Kesehatan Kemenkes Padang. Skripsi. 2015

11. Safitri L. Hubungan nilai ankle brachial index (ABI) dengan kualitas hidup penderita diabetes melitus tipe 
2 di Kota Surakarta. Program Studi Keperawatan Fakultas IImu Kesehatan Universitas Muhammadiyah Surakarta. Skripsi. 2017

12. Damayanti. Efek penggunaan simvastatin terhadap kenaikan gula darah puasa pasien diabetes melitus tipe 2. Journal of Pharmaceutical Science and Clinical Research 2, 1 (1): 58-65. 2010

13. Sutrisno. Manajemen sumber daya manusia. Jakarta : Kencana. 2011

14. Anani. Hubungan antara perilaku pengendalian diabetes dan kadar glukosa darah pasien Rawat Jalan diabetes melitus (Studi Kasus di RSUD Arjawinangun Kabupaten Cirebon). Jurnal Kesehatan Masyarakat, 1 (2): 12-20. 2012

15. Setiadi. Konsep dan proses keperawatan keluarga. Yogyakarta: Graha IImu. 2008

16. Setiyorini E, Ningarti W. Hubungan lama menderita dan kejadian komplikasi dengan kualitas hidup lansia penderita diabetes melitus tipe 2 . STIKes Patria Husada Blitar. Seminar Nasional dan Gelar Produk 17-18 oktober 2017.

17. Arsana. Pengaruh penyuluhan gizi terhadap kepatuhan diet pasien diabetes melitus di Poli Gizi RSU Dr. Saiful Anwar Malang. Majalah Kesehatan FKUB. 2008. http ://scholar.google.co.id. Diakses pada 25 Maret 2015.

18. Notoatmodjo, S. IImu perilaku kesehatan. Jakarta: Rineka Cipta. 2010

19. Tjokroprawiro, A. Garis besar pola makan dan pola hidup sebagai pendukung terapi diabetes melitus. Surabaya: Fakultas Kedokteran Unair. 2012

20. Manan S. Hubungan tingkat pengetahuan dengan kepatuhan dalam upaya mengontrol gula darah di Poliklinik Rumah Sakit Immanuel Bandung tahun 2009. Jurnal Penelitian Sains dan Teknologi,10 (2):130-138. 2009 